PRZEGLĄD RUSYCYSTYCZNY 2020, nr 4(172)

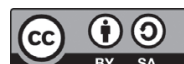

DOI 10.31261/pr.9049

\author{
BEATA PAWLETKO \\ Uniwersytet Śląski w Katowicach \\ (D) ORCID: https://orcid.org/oooo-0oo2-1430-1547
}

\title{
DOŚWIADCZENIE GŁODU: PIOTROGRÓD-LENINGRAD
}

\section{FAMINE EXPERIENCE: PETROGRAD-LENINGRAD}

Reading reminiscences and notes of besieged citizens of Leningrad many times one can come across information concerning famine set in the Russian city during the civil war. It turns out that those two boundary experiences imply many frightening similarities, such as the same mechanism of behavior towards escalating famine. The article attempts to analyze Reminiscences by Dmitry Likhachov from this perspective. The author pays attention to the similarities in describing famine in Petrograd and Leningrad, but also differences. After all, the famine in post-revolutionary Russia is present in Likhachov's witness in the context of reminiscences form his childhood. Whereas, the siege of Leningrad is seen by grown-up man - husband, father, but also son, who in an interesting way records traumatic changes of the body and psychology of besieged man.

Keywords: Leningrad, Piotrograd, Likhachov, famine, reminiscenses, witness

Czytając wspomnienia, zapiski oblężonych leningradczyków, niejednokrotnie można natknąć się na informacje dotyczące głodu, jaki zapanował w mieście podczas wojny domowej. Objął on wówczas wiele guberni rosyjskich, doświadczając szczególnie mieszkańców miast. Julia Chmielewskaja podkreśla, że chociaż Rosja była przyzwyczajona do okresowych klęsk głodu (jako przykład podaje chociażby tę z lat 1891-1892, gdy dochodziło do masowych zgonów wywołanych dystrofią), to jednak głód w porewolucyjnej Rosji był zjawiskiem bez precedensu, jeśli chodzi o rozmiary, a także obszar, jaki objął. Mowa wszak o terytorium od Uralu do Morza Czarnego, a więc tereny zamieszkiwane wówczas przez ponad 30 milionów ludzi. Stereotypowo wspomina się w tym kontekście o głodzie na Powołżu, wiemy jednak, że kataklizm dotknął również mieszkańców Ukrainy, Krymu, Kauka- 
zu, południowego Uralu i Przyuralu ${ }^{1}$. Charakteryzując trudną sytuację w porewolucyjnej Rosji, Richard Pipes zauważa, że miała tam miejsce największa w dotychczasowej historii Europy klęska głodu, pogłębiona na dodatek suszą. I gdyby nie pomoc Amerykańskiej Administracji Pomocy (American Relief Administration), to liczba ofiar śmierci głodowej (około 5,2 miliona ludzi) byłaby jeszcze większa². O działalności ARA w porewolucyjnej Rosji wspomina również Chmielewskaja, zwracając uwagę, że na początku organizacja ta stawiała sobie za cel pomoc głodującym dzieciom, szybko jednak okazało się, że jedzenia brakuje wszystkim, również chłopom. Oprócz żywności ARA dostarczała do Rosji również szczepionki, które pomogły skutecznie walczyć nie tylko z epidemią tyfusu, ale także z cholerą i ospą. Dokonując charakterystyki tej organizacji w oparciu o różne materiały archiwalne, badaczka koncentruje się jednak przede wszystkim na specyfice klęski głodu lat 20.:

Первый советский голодомор, как я называю голод 1921-1922 годов, был официально признан советской властью, охотно принявшей иностранную помощь и допустившей в страну много зарубежных организаций. Также большевики не препятствовали „голодной миграции”, то есть бегству людей из охваченных бедствием мест. Второй советский голодомор 19321933 годов всячески замалчивался, а районы его распространения были оцеплены заградотрядами. [...] информацию о голоде скрывали всеми возможными способами ${ }^{3}$.

1 Zob. Ю. Хмелевская, Обезумевшие родители отбирали еду у детей, бесед. А. Мозжухин, 15.11.2017, https://m.lenta.ru/articles/2017/11/15/golod_1921/ (11.01.2018).

2 R. Pipes, Komunizm, przeł. J.J. Górski, Świat Książki, Warszawa 2008, s. 6263. Podobną liczbę ofiar podaje również Julia Chmielewskaja z PołudniowoUralskiego Uniwersytetu Państwowego w Czelabińsku: „[...] мы до сих пор не знаем точного числа его жертв. По приблизительным оценкам, голод 19211922 годов и сопутствующие ему болезни погубили более пяти миллионов человек”. Więcej zob. Ю. Хмелевская, Обезумевиие родители отбирали еду y детей...

3 Ю. Хмелевская, Обезумевшие родители отбирали еду у детей... O niezależności działań ARA, na czele której stał późniejszy amerykański prezydent Herbert Hoover, pisze również Tomasz Stempowski. Koncentruje się on na ważnym elemencie strategii informacyjnej prowadzonej przez ARA, tj. na fotografiach dokumentujących skalę klęski głodu, które w krótkim czasie nagłośniły akcję pomocy i były zdumiewającym świadectwem, uwieczniały bowiem nie tylko ciężkie warunki życia, ale również ofiary głodu (i to zarówno ciała pojedynczych zmarłych, jak i stosy trupów). Więcej zob. T. Stempowski, Bezlitosne fotografie: głód w Rosji $w$ latach 1921-1923, 12.11.2017, http://fototekst.pl/bezlitosne-fotografie-glodw-rosji-w-latach-1921-1923/ (14.01.2018). Ponadto działalność organizacji ARA 
Jeśli chodzi o Piotrogród, to głód pojawił się wcześniej na przełomie 1917 i 1918 roku, przybierając na sile w kolejnych latach wskutek nieumiejętnego zarządzania i masowych strajków ${ }^{4}$. Nic dziwnego, że w odniesieniu do ówczesnej sytuacji bytowej miasta nad Newą oraz demograficznej zapaści przez analogię używa się określenia „blokada” czy też „pierwsza blokada”. Codzienność w porewolucyjnym Piotrogrodzie, podobnie jak codzienność oblężonego Leningradu stały się obiektem zainteresowania historyków właściwie dopiero w ostatnich latach. Życie codzienne Piotrogrodu poddano analizie m.in. w książce Петроград на переломе эпох. Город и его жители в годы революции и Гражданской войнъь ${ }^{6}$. Czytając o nim, odbiorca - zaznajomiony z realiami oblężonego Leningradu - ze zdumieniem odkrywa, jak wiele zatrważających podobieństw kryją w sobie te dwa doświadczenia graniczne. Przede wszystkim uwagę zwraca ten sam mechanizm zachowań wobec narastającego głodu, tj. włączanie do jadłospisu rzeczy na pozór niejadalnych (np. fusów z kawy czy herbaty, owsa, roślin pastewnych, wytłoków7), tworzenie stołówek i jadłodaj-

można postrzegać w kategoriach ewenementu. Dostrzegalne jest to szczególnie w kontekście krótkotrwałej rosyjskiej inicjatywy pod nazwą Pomgoł. To skrótowiec od słów „Помощь голодающим”, za którym kryje się społeczny Komitet Pomocy Głodującym, powstały w 1921 roku. W prace krótko istniejącego komitetu zaangażowali się znani działacze partyjni, pisarze i ludzie kultury (wśród nich: Maksim Gorki, Władimir Korolenko, Boris Zajcew i Konstantin Stanisławski), lekarze i uczeni, jednak ich starania, by pomóc głodującym, bardzo szybko przerwano, co gorsza, członków komitetu aresztowano i oskarżono o działalność kontrrewolucyjną, cudem uniknęli wyroków śmierci. W konsekwencji jednak wielu z nich musiało opuścić Rosję (np. Gorki) albo zostało zesłanych do łagrów.

4 L. Bazylow, P. Wieczorkiewicz, Historia Rosji, Ossolineum, Wrocław 2005, s. 398.

5 А. Волынец, Первая блокада Петрограда, 7.05.2014, https://rusplt.ru/policy/ blokada-pitera-9693.html (11.11.2017).

6 С. В. Яров, Е. М. Балашов, В.И. Мусаев, А.И. Рупасов, А. Н. Чистиков, Петроград на переломе эпох. Город и его жители в годы революции и Гражданской войны, Центрполиграф, Москва 2013. Warto podkreślić, że w tym samym roku (2013) ukazały się dwie monografie o oblężeniu Leningradu jednego ze współautorów opracowania Петроград на переломе эпох, tj. Siergieja Jarowa (Блокадная этика: представления о морали в 1941-1942 г2 (wydanie trzecie) oraz Повседневная жизнь блокадного Ленинграда).

7 Wytłoki pozostają symbolem „sztuki kulinarnej” zarówno w Piotrogrodzie, jak i w oblężonym Leningradzie. Por. fragmenty Wspomnień Lichaczowa: „A co to sa wytłoki - wystarczy zajść do jakiegoś sklepu z paszą, gdzie sprzedaje się karmę dla bydła. Wytłoki ratowały leningradczyków w obydwu okresach głodu". D. Lichaczow, Wspomnienia, przeł. B. Żyłko, Wydawnictwo „Sedno”, Warszawa 2016, s. 416. Dalej cytuję według tego wydania, w nawiasie po cytacie podając numer strony $-\mathrm{B}$.P. 
ni, system kartkowy, „symboliczne” racje żywnościowe (szczególnie dla osób niepracujących, pozostających na czyimś utrzymaniu), zakładanie w mieście i w dzielnicach podmiejskich warzywników, wymiana różnych towarów na żywność, kradzieże, grabieże, szabrownictwo. Podobieństwa dotyczą również przestrzeni miasta - ciemnej (oszczędność energii elektrycznej, gazu, nafty) i wyludnionej, w której króluje martwa cisza. $\mathrm{Z}$ miejskiego krajobrazu znikają w tamtym czasie drewniane domy, które decyzją władz przeznaczone zostały na opał. Ogołocenie przestrzeni, nagromadzenie sztucznie powstałych ruin i wyrw pozostaje nie bez wpływu na jej odbiór (podobnie będzie to wyglądać na początku lat 40.) ${ }^{8}$. Wadim Musajew, autor rozdziału Городская повседневность (Состояние города. Повседневная жизнь горожан), przytacza w tym kontekście relacje cudzoziemców, którzy odwiedzając Piotrogród (na przykład po uprzedniej wizycie w Moskwie), dostrzegają, że opustoszałe i ciemne ulice oraz place przypominają zaświaty, wymarłe miejsce. Szczególnie dotyczy to osób, które pamiętają jeszcze przedrewolucyjny Petersburg, jak na przykład amerykańska anarchistka Emma Goldman:

Санкт-Петербург всегда оставался в моей памяти яркой картиной, полной жизни и загадочности. Я нашла Петроград 1920 года совершенно другим. Он был почти в руинах, словно ураган пронесся через город. Дома походили на старые поломанные гробницы на заброшенном кладбище. Улицы были грязные и пустынные, вся жизнь ушла с них. Люди проходили мимо, похожие на живых покойников 9 .

Ograniczenia w dostawie prądu i brak żywności, opału oraz wody powodują, że życie mieszkańców Piotrogrodu przynosi zdziczenie obyczajów, prymitywizację zachowań, odczłowieczenie. Ludzie chodzą brudni, ubrani w łachmany i dziurawe buty (często powodem jest wymiana odzieży na produkty żywnościowe, ale również niechęć do wyróżniania się w tłumie). W mieszkaniach centralne miejsce zajmują burżujki - jeden z trzech (oprócz kaganków i sanek dziecięcych) symboli blokady Leningradu. I podobnie jak dwadzieścia lat później

8 Wspominając tamte czasy, Wiktor Szkłowski stwierdza, że przestrzeń miejska wraz ze zniszczonymi i ocalałymi budynkami przypomina wyglądem ryciny Piranesiego. Zob. В.И. Мусаев, Городская повседневность, w: С. В. Яров..., Петроград на переломе эпох..., s. 99. Por. uwagi na temat przestrzeni oblężonego Leningradu zawarte w mojej monografii Blokada Leningradu i jej reprezentacje $w$ świetle innych doświadczeń granicznych, „Śląsk”-SIW, Katowice 2016, s. 162-187.

9 E. Goldman, My disillusionment in Russia, Doubleday, Page \& Company, New York 1923, s. 12. Za: В. И. Мусаев, Городская повседневность..., s. 96. 
za „polana” posłużą książki, meble, parkiet, drzwi. Ilustracją znaczenia burżujki dla mieszkańców porewolucyjnego miasta jest utwór Jewgienija Zamiatina Jaskinia. Piecyk w tym symptomatycznie zatytułowanym opowiadaniu określony został mianem „boga jaskini”:

Krótkonogi, rdzaworudy, przysadzisty, chciwy bóg jaskini - piecyk żelazny [...] huczał potężnie. W pomroce jaśniał - wspaniałym cudem ognia. Ludzie [...] w milczeniu, z pokorą i wdzięcznością wyciągali do niego ręce. Na całą godzinę do jaskini wkraczała wiosna. Na całą godzinę zrzucić można było z siebie skóry zwierzęce i różne łachmany, a pod zlodowaciałą korą mózgową zaczynały się wtedy wykłuwać zielone pędy - pojawiały się myśli ${ }^{10}$.

„Jaskinia”, czyli typowe piotrogrodzkie mieszkanie, to przestrzeń, której atrybutami są lodowate narośle na ścianach, oblodzone schody, ciemne sklepienia, kołyszące się cienie, kamienna siekierka, młynek do kawy, w którym mieli się wysuszone obierki ziemniaków. To miejsce, „gdzie człowiek zredukowany do zwierzęcia skupiony jest na walce o byt [...], nie ma wyboru między dobrem a złem, jest wyłącznie wybór między złem mniejszym i większym" ${ }^{11}$.

Poza prozą i eseistyką Zamiatina temat traumatycznej, „głodnej”, porewolucyjnej codzienności Piotrogrodu pojawia się również w diariuszu pisarki Zinaidy Gippius, literaturoznawcy i autora literatury dziecięcej Kornieja Czukowskiego czy we wspomnieniach malarza, grafika, przedstawiciela rosyjskiej awangardy Jurija Annienkowa. W niniejszym szkicu chciałabym poświęcić uwagę wspomnieniom filologa Dmitrija Lichaczowa. Badacz ten pozostawił po sobie niezwykłe świadectwo, w którym jedną z głównych ról odegrał właśnie głód. Autor Poetyki literatury staroruskiej opisuje doświadczenie głodu nie tylko z perspektywy życia w Piotrogrodzie i Leningradzie, ale wspomina również o głodzie w kontekście łagrów - Lichaczow trafił na Sołowki w 1928 roku (a więc mając zaledwie 22 lata).

Zapiski Lichaczowa, podobnie jak opowiadania Zamiatina, potwierdzają, że jedynym antidotum na głód i wynikające $\mathrm{z}$ niego upodlenie jest próba ocalenia w sobie człowieczeństwa, nieuleganie prymitywnym instynktom, praca fizyczna i umysłowa, ale przede wszystkim praca nad sobą, tj. podjęcie wysiłku, by za wszelką cenę zachować godność. I to wszystko w codzienności, pozbawionej nie-

${ }^{10}$ J. Zamiatin, Jaskinia, przeł. Z. Podgórzec, w: tegoż, Jaskinia, przeł. M. Putrament, Z. Podgórzec i in., Wydawnictwo „Łuk”, Białystok 1993, s. 201.

${ }^{11}$ Z. Podgórzec, Posłowie, w: J. Zamiatin, Jaskinia..., s. 429. 
zbędnych dla ciała i duszy elementów, tj. jedzenia i opału ${ }^{12}$. Charakteryzując życie w porewolucyjnym Piotrogrodzie, filozof Fiodor Stiepun odnotowuje, że w tamtym czasie pojawiały się w mieście liczne kółka filozoficzne czy historyczne, powstawało, ale też pozostało po poprzedniej, carskiej epoce, wiele instytucji, które stanowiły enklawy życia kulturalnego, chociaż:

Когда оглядываешься назад, [...] трудно поверить, что полуголодные люди могли собираться несколько раз в неделю в плохо освещенных и неотапливаемых помещениях, чтобы по три-четыре часа кряду обсуждать философские проблемы и слушать стихи. [...] Главной темой бесед был духовный, а не материальный развал: говорили о кризисе культуры, о смыслах истории и жизни ${ }^{13}$.

Jedną z takich inicjatyw był Instytut Historii Sztuk, założony przez hrabiego Walentina Zubowa w 1912 roku. To w jego pałacu, będącym siedzibą Instytutu, znaleźli przystań m.in. głodujący studenci, pisarze, ludzie kultury czy przedstawiciele duchowieństwa. We wspomnieniach Zubowa odnajdujemy nie tylko informacje o głodzie i wymianie towarowej, ale również o niezwykłej atmosferze panującej w Instytucie:

nie marzłem tak jak większość mieszkańców stolicy i - co najważniejsze byłem otoczony uczniami i współpracownikami, którzy tworzyli jedną wielką rodzinę. Instytut był dla nich w tych dniach boleści i głodu duchowym centrum, a także azylem socjalnym. Pomagaliśmy sobie nawzajem przetrwać trudy czasu. Przez osiem lat stanowił oazę na umysłowej pustyni, której beznadziei nie da się opisać. Setki ludzi, którym poza naszymi murami groziło fizyczne i moralne wyniszczenie, znajdowały tu strawę duchową i problemy zmuszające do zapomnienia o codziennych troskach, osaczających zewsząd aż do mdłości. Tu natomiast, pogrążeni w sprawach naukowych i artystycznych, odrywali się od zgrozy panującej na zewnątrz, zapominali o krwi, która się przelewała. Jak silnie ludzie odczuwali to szczęście, świadczy fakt, że wielu studentów mieszkających w odległości godziny marszu od Instytutu przychodziło po dwa razy dziennie, co w pozbawionym transportu mieście oznaczało dla nich ponad cztery godziny drogi ${ }^{14}$.

Nawiązując do działalności tej i innych instytucji naukowych i kulturalnych, które mimo dramatycznych warunków bytowych i głodu

${ }^{12}$ Por. A. Gildner, Proza Jewgienija Zamiatina, Uniwersytet Jagielloński, Kraków 1993, s. 82.

${ }^{13}$ Cуt. za: В. Зубок, Дмитрий Лихачев: жизнь и век (главы из книги), „Звезда” 2016, nr 11, http://magazines.russ.ru/zvezda/2016/11/dmitrij-lihachev-zhizn-ivek.html (12.12.2017).

${ }^{14}$ W. Zubow, Lata przez mękę Rosja 1917-1925, przeł. D. Ulicka, Wydawnictwo „Sedno”, Warszawa 2015, s. 132. 
starały się w porewolucyjnej, wojennej rzeczywistości funkcjonować normalnie, warto odnieść się do zapisków Lichaczowa, który najpełniej zaobserwował wpływ głodu na ludzki organizm podczas oblężenia. Badacz zwraca uwagę, że w sytuacji, gdy ciało odmawiało już człowiekowi posłuszeństwa, mózg pracował nadal: „ludzie pisali dzienniki, dzieła filozoficzne, prace naukowe, szczerze, z głębi duszy myśleli, przejawiali niezwykłą twardość, nie ustępując naciskowi, nie poddając się marności i próżności” (s. 437), [...] dystrofia nie odbijała się na pracy mózgu" (s. 449). Praca nad sobą, wysiłek intelektualny, uczenie się z dziećmi wierszy na pamięć stają się we wspomnieniach Lichaczowa jedyną ucieczką od głodu, zimna, natrętnych myśli o jedzeniu.

Głód w porewolucyjnej Rosji pojawia się w świadectwie Lichaczowa przy okazji reminiscencji z okresu dzieciństwa. Po rewolucji październikowej, którą, jak sam przyznaje, słabo pamięta (miał wówczas 11 lat), w życiu jego rodziny zachodzą zmiany dotyczące chociażby wakacyjnych wyjazdów na daczę. Po zamknięciu granicy fińskorosyjskiej niemożliwe stają się pobyty w ukochanej miejscowości Kuokkali, „gdzie ukształtowały się petersburskie obyczaje letniskowe" (s. 114). Dlatego rodzina Lichaczowów spędza czas letni w innych miejscowościach, m.in. w Olginie. Niestety, życie letniskowe po 1917 roku nie jest już zupełnie beztroskie, następuje bowiem czas głodu. Jak pisze przyszły badacz:

Z rana wyruszałem do Konnej Łachty w poszukiwaniu mleka, które mógłbym kupić lub wymienić. Miejscowi chłopi zazwyczaj chłodno odmawiali lub zgadzali się na ograniczoną wymianę; zachowywali się z poczuciem wyższości. Suszyłem na zimę liście czarnej porzeczki i malin na herbatę [...] (s. 114).

We wspomnieniach pojawia się i migawka z „głodnego" Piotrogrodu. Przypominając sobie, dlaczego doszło do przenosin ze szkoły Maja do szkoły Lentowskiej, znajdującej się w pobliżu mieszkania służbowego, Lichaczow wyjaśnia:

jeżdżenie do szkoły w przepełnionych tramwajach stało się niemożliwe, chodzenie pieszo - jeszcze trudniejsze, gdyż w ówczesnym Petersburgu były okropne problemy z żywnością. Jedliśmy makuchy (prasowane wytłoczyny), chleb z owsa z paździerzami, czasem udawało się zdobyć trochę zmarzniętych kartofli, po mleko chodziliśmy pieszo na Łachtę, gdzie otrzymywaliśmy je w zamian za rzeczy (s. 117).

Najczęściej jednak głód porewolucyjny kojarzony jest z tragedią oblężenia. Nawet wtedy, kiedy Lichaczow opisuje swojego ukocha- 
nego nauczyciela, Leonida Georga, którego spotkał w tramwaju już po ukończeniu szkoły, komentarz wychowawcy dotyczący własnego wyglądu - „Nie przytyłem, lecz spuchłem!” (s. 127) - odbieramy poprzez pryzmat blokady Leningradu i wiedzy o przemianach ludzkiego ciała następujących w rezultacie choroby głodowej. Po doświadczeniach głodu przełomu lat 10. i 20. mieszkańcy miasta nad Newą nauczyli się, jak walczyć z klęską głodową. Wiele praktycznych porad, wykorzystywanych w trakcie blokady Leningradu, pochodziło z porewolucyjnego Piotrogrodu. Dotyczyły one np. robienia kaganków czy gromadzenia zapasów:

Przed naszym powrotem z Wyricy do Leningradu wprowadzono już system kartkowy. Sklepy stopniowo pustoszały. Żywności, sprzedawanej na kartki, było coraz mniej: znikały konserwy, żywność drożała. Ale chleba w pierwszym okresie na kartki wydawano wiele. Nie zjadaliśmy go w całości, gdyż dzieci jadły mało chleba. Zina nawet nie chciała wykupywać całego przysługującego nam chleba, ale ja nalegałem: stawało się jasne, że będzie głód. Bałagan się powiększał. Dlatego suszyliśmy chleb na słońcu na parapetach. Do jesieni nasuszyliśmy dużą poszewkę czarnych sucharów. Powiesiliśmy ją na ścianie, chroniąc przed myszami. Później zimą myszy wymarły z głodu. Mroźnym rankiem w ciszy, kiedy już leżeliśmy w łóżkach, słyszeliśmy, jak umierająca mysz konwulsyjnie skakała gdzieś pod oknem i potem zdychała: ani jednej okruszyny nie mogła znaleźć w naszym pokoju. [...] robiliśmy wszystko, żeby zebrać niewielkie zapasy na zimę (s. 399).

Dlatego z taką bezwzględnością podchodzono często do nestorów rodu, którzy podczas blokady prosili swoich bliskich o chleb, chociaż byli to ludzie, którzy przeżyli już jedną klęskę głodu i, nauczeni doświadczeniem, powinni byli zaopatrzyć się w zapasy żywności. W takim kontekście Lichaczow wspomina wujka Wasię, nader religijnego człowieka, który po rewolucji pracuje w Banku Państwowym, a właściwie przyłącza się do trwającego kilka miesięcy strajku urzędników bankowych. W tym czasie nie chodzi do pracy, co oznacza, że rodzina w obliczu klęski głodu musi wyprzedawać różne rzeczy, aby przeżyć. Ciąg dalszy tej historii dopisuje właśnie blokada. To wtedy, jak wielu innych bliskich i dalszych krewnych, wujek umiera. Ważne są jednak okoliczności i komentarz Lichaczowa:

W domu w ogóle nie dawano mu jeść. Zjawił się u nas na początku blokady, poprosił o kawałek chleba i przyniósł drogie lalki dla dzieci. Lalki można było wtedy kupić, ale chleba nie. Przyszedł do wujka Szury, padł w przedpokoju na kolana, błagając o kromkę chleba. Ale skąpy Szura nic nie dał. To niejedyny przypadek, kiedy podczas blokady rodzina odmawiała jedzenia swemu nestorowi, zarzucając mu, że zawczasu nie przygotował zapasów, nie poszedł do pracy i zgubił 
kartki żywnościowe lub skierowanie do stołówki. W jakiej zbiorowej mogile zakopano wujka Wasię - nie wiem (s. 27).

Lichaczow widzi wujka poprzez pryzmat spójności całego jego życia, indywidualizmu, wierności swoim zasadom niezależnie od okoliczności. Takie spojrzenie obce jest rodzinie wujka Wasi, ale tak naprawdę było obce wielu wygłodniałym, niebędącym sobą ludziom. Ze świadectw pochodzących $\mathrm{z}$ okresu oblężenia wiemy, że relacje międzyludzkie i rodzinne ulegają w tym czasie nie tylko rozluźnieniu, ale często także zupełnemu zniszczeniu. Wujek, z którym Lichaczow rozmawiał w młodości na ważne tematy, a nawet się spierał, pojawia się we wspomnieniach dwukrotnie, tak jakby badacz wywiązywał się z deklaracji złożonej we wstępie: „[...] czy warto pisać wspomnienia? Warto - żeby utrwalić zdarzenia, atmosferę dawnych lat, ale najważniejsze, żeby pozostał ślad po ludziach, których być może nikt nigdy więcej nie wspomni, o których kłamią dokumenty" (s. 9, rozstrzelenie moje - B.P.).

Skala głodu podczas pierwszej zimy w oblężeniu zaskoczyła nawet tych spośród leningradczyków, którzy - jak Lichaczowowie - zrobili zapasy $^{15}$. Nic dziwnego, że w miesiącach zimowych rozdrażnieni, wygłodzeni ludzie zamęczali siebie nawzajem pytaniem o to, dlaczego nie kupili więcej jedzenia. To pytanie zadawał sobie również Lichaczow, chociaż w lipcu 1941 roku, już po rozpoczęciu działań wojennych, jak mantrę powtarzał słowa: „Będzie głód, będzie głód” (s. 399). Doświadczenie głodu w oblężonym Leningradzie, choć pod wieloma względami podobne do tego w porewolucyjnym Piotrogrodzie, pozostaje dla Lichaczowa jednak zupełnie innym przeżyciem. Tamto widziane było z perspektywy beztroskiego dzieciństwa, to przeżywane jest przez dorosłego, dojrzałego człowieka, głowę rodziny, męża, ojca, ale i syna. Wstrząsające wrażenie wywołuje szczególnie opis traumatycznej relacji z ojcem, stopniowe oddalanie się od siebie mężczyzn, zintensyfikowane - w związku z zaostrzającą się na skutek dystrofii patologiczną chciwością Lichaczowa seniora - gesty wrogości, podejrzliwości, wzajemne oskarżenia i pretensje, wiele mówiące o niszczącej sile głodu, a także wymuszony przez okoliczności prymitywny

${ }^{15}$ Warto w tym miejscu wymienić te zapasy. W liście do Walentiny Gałaktionowny Morozowej-Keller Lichaczow pisze: „Udało nam się kupić z dziesięć kilogramów ziemniaków, dwanaście kilogramów kaszy i makaronów, jeden kilogram masła i nasuszyć dwa wielkie worki sucharów" (s. 463). Oprócz tego autor wspomina o jedenastu stugramowych buteleczkach tranu oraz dziesięciu tabliczkach witamin z glukozą. 
w formie pochówek w mogile zbiorowej i stłumiona chorobą głodową żałoba. Na drugim biegunie uczuć pozostaje natomiast miłość do żony Ziny i bezgraniczna wobec niej wdzięczność za stanie w kolejkach, wyprawy po wodę nad Newę, palenie w piecu, troskę o najbliższych. Czytając retrospektywne zapiski, można przypuszczać, że o ile relacja z ojcem została wystawiona na dramatyczną próbę, o tyle uczucie do żony i dzieci w trakcie oblężenia jeszcze bardziej się nasiliło, chociaż niszczycielski żywioł głodu nie pozostał bez wpływu na psychikę członków rodziny Lichaczowów. Co ciekawe, badacz rejestruje przemiany w zachowaniu ojca, swoim i dzieci:

Jura [Jurij Lichaczow - młodszy brat Dmitrija - B.P.] z Ninoczką (swoją drugą żoną) wyjechał drogą śmierci w samochodzie, który był wyposażony jak mieszkanie. Przed wyjazdem Jura obiecał przysyłać jedzenie. Ojciec czekał na to jedzenie ze straszną niecierpliwością: wciąż myślał o tym, że Jura przyśle wędzoną kiełbasę. Cały czas mówił o jedzeniu, wspominał obiady na wołżańskich statkach i kiedy jadł zupę (a raczej to, co nazywaliśmy zupą), to bardzo sapał. Mnie, ogarniętego już rozdrażnieniem spowodowanym dystrofią, złościło to sapanie (nie rozumiałem tego, że winne jest serce) i ta wędzona kiełbasa, na którą tak czekał... (s. 433).

W lutym zaopatrzenie nieco się poprawiło [...]. Dziewczynki wychodziły na dziesięciominutowe spacery kuchennym wejściem, a nie frontowym, gdzie leżeli martwi. Zachowywały się bohatersko. Stały się ponad wiek dorosłe, nieruchliwe, śmiertelnie poważne (s. 466).

I właściwie jedynymi osobami z jego otoczenia, które pozostają sobą, są kobiety, tj. matka, ale przede wszystkim żona. To w odniesieniu do niej pojawiają się najczęściej krótkie komentarze podkreślające zbawienną dla rodziny Lichaczowów rolę Ziny: „całą naszą rodzinę ratowała Zina” (s. 427), „całe gospodarstwo domowe spoczywało na Zinie” (s. 463), „[...] to co najważniejsze robiła Zina” (s. 467).

Wspomnienia Lichaczowa charakteryzuje prostota stylu, opowieści są nierzadko bardzo lapidarne, jakby zapisane mimochodem, chociaż tematyka, „ciężar” przekazywanych informacji poraża. W niewyszukanych, lakonicznych zdaniach nie znajdziemy żadnej pozy czy maski, brak tu megalomanii, patosu, skargi, prób wyolbrzymiania własnego cierpienia, oskarżycielskich nut. Niemal w każdej sytuacji 
badacz stara się dostrzec jasne strony życia, dobro innych ludzi, ich pasje, piękno otaczającej przyrody czy architektury. To na nich skupia uwagę, o nich pisze wyczerpująco, z czułością, ale i z tęsknotą. Z kolei o przejawach zła w Piotrogrodzie, na Sołowkach i w oblężonym Leningradzie wypowiada się krótko, ale sprawiedliwie, bezkompromisowo, bez tuszowania wynaturzeń, patologii, przemocy, ludzkich słabości. Przede wszystkim jednak wspomnienia skoncentrowane są na imperatywie pamięci o ludziach i miejscach, o odchodzącym świecie, o historiach, które przerwały swój bieg (s. 116). Jako ilustracja może tu posłużyć próba nakreślenia wyjątkowej atmosfery przedrewolucyjnego Petersburga. Lichaczowowi udaje się oddać genius loci ówczesnej rosyjskiej stolicy. Powstaje niezwykła, różnorodna dźwiękowo-zapachowo-wizualna mapa miasta. Uwaga skupiona jest na architektonicznych detalach, realiach, obyczajach, ciekawostkach, anegdotach, ale również przemianach, kreślonych spokojną, nostalgiczną, melancholijną nierzadko kreską. I tu przykładem może być opis zmieniającego się zapachu ulicznego powietrza:

Inny stał się zapach ulicznego powietrza, nawet jego kontakt ze skórą twarzy. Dziesiątki tysięcy koni owiewających swoim ciepłem przechodniów czyniły powietrze miasta mniej oficjalnym. Nie przejęzyczyłem się: właśnie mniej oficjalnym, mniej obojętnym wobec człowieka (s. 59).

Dla Lichaczowa niezmiernie ważne staje się odtworzenie polifonii petersburskiej kultury, jej demokratycznego charakteru, który z czasem będzie musiał ustąpić miejsca monologicznej kulturze dyktatury proletariatu (s. 168).

Uczeń autora Poetyki literatury staroruskiej, współczesny prozaik Jewgienij Wodołazkin, zauważa, że wyjątkowość spojrzenia badacza, jego delikatność, wyrozumiałość, łagodność, dobroć w odniesieniu do innych ludzi, ma bezpośredni związek ze szczęśliwym, beztroskim dzieciństwem. W tekście Одеяло Лихачева Wodołazkin nawiązuje do rozdziału Wspomnień zatytułowanego Przekatna dziecięcej kotdry. Dowiadujemy się z niego, że bliscy przed wyprawą na Sołowki wyposażyli młodego Lichaczowa w niewielki materacyk oraz dziecięcą puchową kołderkę, która ogrzewała go w obozie nie tyle fizycznie, ile siłą pamięci o domu, rodzinie, uniwersytecie i Petersburgu. Zdaniem Wodołazkina, pamięć o szczęśliwym dzieciństwie, wdzięczność za nie, a także miłość, którą Lichaczow otrzymał od rodziców, nie tylko pomaga mu przetrwać wiele traumatycznych chwil, 
lecz także sprawia, że jego wspomnienia w znacznym stopniu oscylują wokół poszukiwania w człowieku dobra ${ }^{16}$, co szczególnie wyraźnie widać w części poświęconej blokadzie Leningradu. Autor Poezji ogrodów konstatuje, że głód to autentyczne życie, to weryfikacja ludzkich postaw, zachowań, słabości: „W czasie głodu ludzie dali się poznać, obnażyli się, uwolnili od wszelkiego blichtru: jedni okazali się wspaniałymi, bezprzykładnymi bohaterami, inni - łajdakami, zabójcami, kanibalami. Środka nie było. Wszystko było prawdziwe" (s. 437).

Słowem kluczem w odniesieniu do Wspomnień pozostaje zatem pamięć, będąca niezmiernie istotnym komponentem ludzkiej tożsamości. To dlatego, jak zauważa Władisław Zubok, autor książki Дмитрий Лихачев: жизнь и век: „Для Лихачева поговорка: 'Не вспоминай прошлогодний снег - что было, то прошло' - не имела смысла. Прежняя Россия, уверял он себя, не исчезла бесследно и навеки" ${ }^{17}$. Potwierdzenie tych słów przynosi pierwsze zdanie rozdziału Wspomnień, poświęconego blokadzie Leningradu: „Wierzę, że nic nie znika, wszystko pozostaje również poza polem naszej świadomości" (s. 392). I chociaż, o czym świadczą retrospektywne notatki badacza, przeszłości często nie da się ocalić materialnie, można ją spróbować ocalić od zapomnienia, przechować w pamięci, przelać na papier, również po to, by w przyszłości móc ją od-tworzyć, skorzystać z bezcennych wskazówek, porad, które, jak pokazuje zapis doświadczenia głodu w Piotrogrodzie i Leningradzie, niejednokrotnie mogą ocalić komuś życie.

\section{REFERENCES}

Bazylow, Ludwik. Wieczorkiewicz, Paweł. Historia Rosji. Wrocław: Ossolineum, 2005.

Gildner, Anna. Proza Jewgienija Zamiatina. Kraków: Uniwersytet Jagielloński, 1993.

Goldman, Emma. My disillusionment in Russia. New York: Doubleday, Page \& Company, 1923.

Khmelevskaya, Yuliya. "Obezumevshiye roditeli otbirali yedu u detey.” Besed. Mozzhukhin, Andrey. 15.11.2017 [Хмелевская, Юлия. “Обезумевшие родители отбирали еду у детей.” Бесед. Мозжухин, Андрей. 15.11.2017] < https://m.lenta. ru/articles/2017/11/15/golod_1921/>.

Lichaczow, Dmitrij. Wspomnienia. Transl. Żyłko, Bogusław. Warszawa: Wydawnictwo "Sedno", 2016.

${ }^{16}$ Е. Водолазкин, Одеяло Лихачева, http://evgenyvodolazkin.ru/461_evgenijvodolazkin-odeyalo-lixacheva/ (30.11.2017).

17 В. Зубок, Дмитрий Лихачев... 
Musayev, Vadim Ibragimovich. "Gorodskaya povsednevnost'.” Yarov, Sergey Viktorovich. Balashov, Yevgeniy Mikhaylovich. Musayev, Vadim Ibragimovich. Rupasov, Aleksandr Ivanovich. Chistikov, Aleksandr Nikolayevich. Petrograd na perelome epokh. Gorod $i$ yego zhiteli v gody revolyutsii i Grazhdanskoy voyny. Moskva: Tsentrpoligraf, 2013. 95-194 [Мусаев, Вадим Ибрагимович. “Городская повседневность.” Яров, Сергей Викторович. Балашов, Евгений Михайлович. Мусаев, Вадим Ибрагимович. Рупасов, Александр Иванович. Чистиков, Александр Николаевич. Петроград на переломе эпох. Город и его жители в годы революции и Гражданской войны. Москва: Центрполиграф, 2013. 95-194].

Pawletko, Beata. Blokada Leningradu i jej reprezentacje $w$ świetle innych doświadczeń granicznych. Katowice: "Śląsk"-SIW, 2016.

Pipes, Richard. Komunizm. Transl. Górski, Jan Jerzy. Warszawa: Świat Książki, 2008.

Stempowski, Tadeusz. "Bezlitosne fotografie: głód w Rosji w latach 1921-1923." 12.11.2017, <http://fototekst.pl/bezlitosne-fotografie-glod-w-rosji-w-latach-1921 $-1923 />$.

Vodolazkin, Evgeniy Germanovich. “Odeyalo Likhacheva.” [Водолазкин, Евгений Германович. “Одеяло Лихачева”] <http://evgenyvodolazkin.ru/461_evgenij-vodolazkin-odeyalo-lixacheva/>.

Volynets, Aleksey Nikolayevich. "Pervaya blokada Petrograda." 7.05.2014 [Волынец, Алексей Николаевич. “Первая блокада Петрограда.” 7.05.2014] <https://rusplt.ru/policy/blokada-pitera-9693.html>.

Yarov, Sergey Viktorovich. Balashov, Yevgeniy Mikhaylovich. Musayev, Vadim Ibragimovich. Rupasov, Aleksandr Ivanovich. Chistikov, Aleksandr Nikolayevich. Petrograd na perelome epokh. Gorod i yego zhiteli $v$ gody revolyutsii $i$ Grazhdanskoy voyny. Moskva: Tsentrpoligraf, 2013 [Яров, Сергей Викторович. Балашов, Евгений Михайлович. Мусаев, Вадим Ибрагимович. Рупасов, Александр Иванович. Чистиков, Александр Николаевич. Петроград на переломе эпох. Город и его жители в годы революиии и Гражданской войны. Москва: Центрполиграф, 2013].

Zamiatin, Jewgienij. Jaskinia. Transl. Putrament, Maria \& Podgórzec, Zbigniew, et al. Białystok: Wydawnictwo "Łuk", 1993.

Zubok, Vladislav Martinovich. "Dmitriy Likhachev: zhizn' i vek (glavy iz knigi).” Zvezda 2016, no. 11 [Зубок, Владислав Мартинович. “Дмитрий Лихачев: жизнь и век (главы из книги).” Звезда 2016, № 11] < http://magazines.russ. $\mathrm{ru} /$ zvezda/2016/11/dmitrij-lihachev-zhizn-i-vek.html>.

Zubow, Walentin. Lata przez mękę Rosja 1917-1925. Transl. Ulicka, Danuta. Warszawa: Wydawnictwo "Sedno", 2015. 